Bogusław GÓRKA

\title{
SADZAWKA BETHESDA $(J$ 5, 2) W PATRYSTYCZNEJ I WSPÓŁCZESNEJ EGZEGEZIE
}

Piąty rozdział czwartej Ewangelii otwiera dwuwiersz, tworzący współrzędne czasowo-przestrzenne, w ramach których usytuował Jan fakt uleczenia chorego przy wodach sadzawki: $(5,1-2)$ : „Po tym było święto Judejczyków i Jezus wszedł do Jerozolimy. Jest zaś w Jerozolimie przy Owczej (bramie) sadzawka nazwana po hebrajsku Bethesda, pięć portyków mająca" [Metò

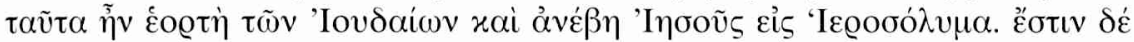

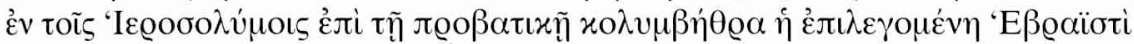

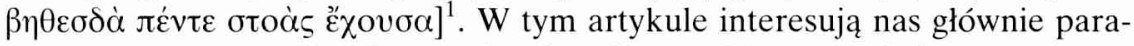
metry przestrzenne określone w drugim wierszu. W tym punkcie napotykamy na mnóstwo trudności, albowiem nie tylko przytoczony przekład jest rzeczą dyskusyjną, ale kwestią otwartą pozostaje nawet ustalenie tekstu autentycznego. Ten zaproponowany przez wydawców tekstu krytycznego traktujemy jako wyjściowy, wywoławczy.

1. Lokalizacja sadzawki. Do czasu przypadkowego odkrycia ruin Bethesdy dokonanego przez Ojców Białych w 2. poł. XIX wieku, sadzawkę lokalizowano w co najmniej pięciu miejscach. Do najbardziej znanych zalicza się sadzawkę Siloe $^{2}$, zasilaną wodą ze źródła Gihon oraz Birket Israil - zbiornik wodny leżący blisko bramy owczej, zbudowany przez Heroda Wielkiego jako rezerwuar świątynny ${ }^{3}$. Wykopaliska, trwające 100 lat, rzuciły światło na cały opis uleczenia chorego $(\mathbf{J} 5,5-9)$ i rozwiązały wiele kwestii, przy czym wzbudziły

${ }^{1}$ Por. Grecko-polski Nowy Testament. Wydanie interlinearne z kodami gramatycznymi, thum. R. Popowski - M. Wojciechowski, Warszawa 1994, s. 412. W przekład wniosłem jedną innowację: wprowadziłem Bethesdę w miejsce Bethzathy preferowanej przez tłumaczy, którzy postępują tu za krytycznymi wydaniami Nowego Testamentu.

${ }^{2}$ Już Efrem Syryjczyk w IV wieku zrównał Bethesdę z sadzawką Siloe, zob. J. Jeremias, The Rediscovery of Bethesda. John 5, 2, Louisville 1966, s. 15, nota 26 - z powołaniem się na M.J. Boismard'a.

${ }^{3}$ Te i pozostałe miejsca omawia D.J. Wieand w: John V,2 and the Pool of Bethesda, „New Testament Studies" 12(1965-1966) 392-404, spec. 396-397. 
nowe. Zacznijmy prezentację zagadnienia od identyfikacji przestrzennej tego, co zostało nazwane przez Jana słowem kolymbethra. Oto zestaw wariantów tekstualnych, które oferują nam manuskrypty czwartej Ewangelii ${ }^{4}$ :

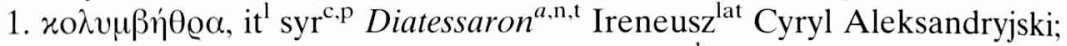

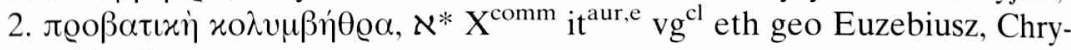
zostom, Teodor;

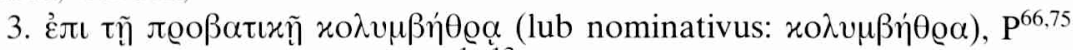
B C K W ${ }^{\text {supp }} \Delta \Pi \Psi 0630780125 f^{1} f^{13} 28335657008921009101010711079$ 119512161230124112421253134413651546164621482174 Byz Lect it ${ }^{\mathrm{c}, \mathrm{f}}$ $\mathrm{vg}^{\mathrm{ww}} \mathrm{syr}^{\mathrm{h} \text { (pal) }} \operatorname{cop}^{\text {sa,bo,ach/2 }}$ arm;

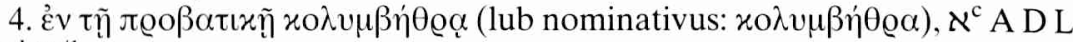
$\Theta$ it $^{\mathrm{d}, \mathrm{q}, \mathrm{r} / \mathrm{1}}$

Lekcje 1. i 2. unikają trudności, które stwarzają 3. i 4. przez to, że upraszczają i wygładzają tekst, i uznaje się je za drugorzędne. W wariantach 3 . i 4

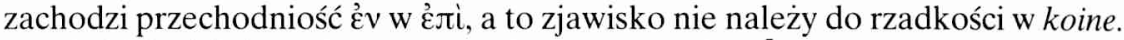
Przyimki દ’v i દ̉ंi trzeba odczytać jako: przy, blisko ${ }^{5}$. Najwięcej kontrowersji

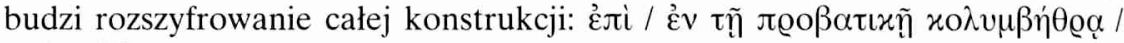
$\varkappa 0 \lambda v \mu \beta \eta \dot{\eta} \theta \alpha$ od strony gramatycznej. Trzeba pamiętać, że tekst oryginalny został zapisany bez akcentów, przydechów, jota subscriptum i przerw międzywyrazowych.

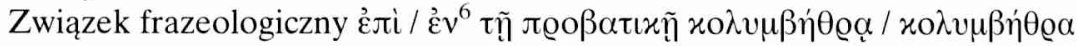
może zostać odczytany na dwa sposoby. W pierwszym wypadku kładziemy $\varkappa 0 \lambda v \mu \beta \eta \theta \varrho \alpha$ w celowniku z jota subscriptum ( $\varkappa 0 \lambda v \mu \beta \eta \dot{\theta} \theta \alpha)$. Wówczas słowo

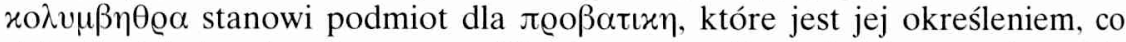
daje przekład: sadzawka owcza. W tej propozycji przyimki są zbędne i ich

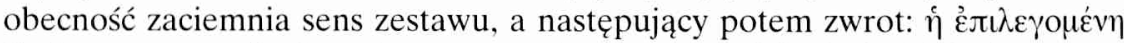
(który nazywany jest) ogołocony zostaje z punktu odniesienia. Jednak na rzecz tej propozycji zaangażował się J. Jeremias, autor ważnego dzieła o sadzawce. Tłumaczy on to miejsce następująco: „Now at the Sheep Pool in Jerusalem there is a place with five colonnades. Its name in the language of the Jews is Bethesda (Przy sadzawce owczej w Jerozolimie znajduje się miejsce z pięcioma portykami. Nazywa się ono po hebrajsku Bethesda - B.G.)" "7 . W tym wypadku

${ }^{4}$ Por. aparat krytyczny ad locum: The Greek New Testament, ed. B. i K. Aland - M. Black J. Karavidopoulos - C.M. Martini - B.M. Metzger, Stuttgart ${ }^{4}$ 1994; Novum Testamentum Graece et Latine, ed. E. i E. Nestle - K. Aland, Stuttgart ${ }^{27} 1996$.

${ }^{5}$ Por. D.J. Wieand, John V,2 and the Pool of Bethesda, art. cyt., s. 392.

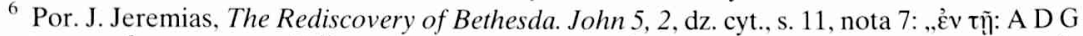

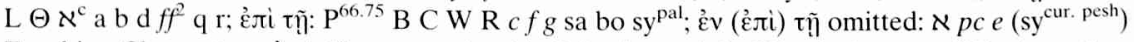
Eusebius, Chrysostom. $\dot{\varepsilon} v(\tau \tilde{\eta})$ as transmitted in Palestine and the West is the most difficult reading. To remove the difficulty, $\dot{\varepsilon} v$ has been corrected to $\dot{\varepsilon} \boldsymbol{\jmath}$, or the preposition and the following article have been cancelled".

${ }^{7}$ Por. The Rediscovery of Bethesda. John 5, 2, dz. cyt., s. 9. Jest to druga edycja, poszerzona, a przygotowana dla wydania w języku angielskim. Do niej z reguły odwołujemy się, poza wyjątka- 
Bethesda nie byłaby nazwą sadzawki, lecz budowli przy niej. Niektóre argumenty J. Jeremiasa uchylił D.J. Wieand ${ }^{8}$. Jeden pozostaje jednak niepodwa-

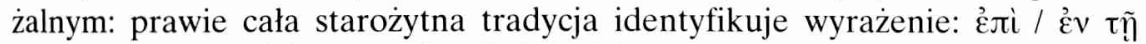

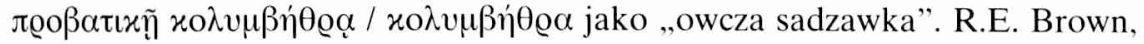
akceptuje tę interpretację, bowiem, według niego, obydwie propozycje domagają się, dla właściwego odczytania sensu całej lekcji, wprowadzenia w tekst jakiegoś pomocniczego słowa. W tym wypadku jest to termin „miejsce”, , doprecyzowane następnie hebrajską nazwą.

A oto druga tendencja odczytania. Tutaj $\varkappa 0 \lambda v \mu \beta \eta \theta \varrho \alpha$ ustawia się w mia-

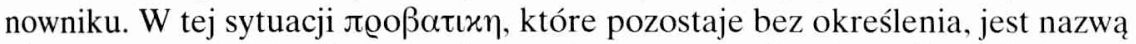

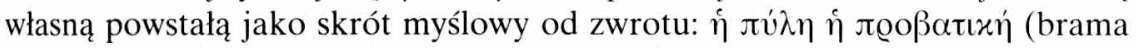
owcza), określającego jedną z bram Jerozolimy u Nehemiasza (3, 1. 32; 12, $39)^{10}$. Supozycja ta prowadzi do przekładu tego rodzaju: „Znajduje się w Jerozolimie przy bramie owczej sadzawka, zwana po hebrajsku Bethesda, zaopatrzona w pięć portyków". Przeciwko tej propozycji podnosi się zarzut literacki ${ }^{11}$

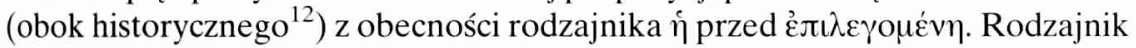
ten nie powinien tu stać, jeśli go nie ma przed $x \circ \lambda v \mu \beta \eta \dot{\theta} \propto \alpha$, lub dopowiedzenie $\dot{\eta} \varepsilon \dot{\pi} \iota \lambda \varepsilon \gamma o \mu \varepsilon \dot{v} \eta$ nie należy odnosić do $x о \lambda v \mu \beta \eta \dot{\theta} \theta \alpha$ pozbawionej tego rodzajni$\mathrm{ka}^{13}$. Z kolei D.J. Wieand wykazuje bezpodstawność tych obiekcji na bazie greckiego uzusu językowego ${ }^{14}$.

Nikt jednak, celem zadowalającego wyjaśnienia obecności tu rodzajnika $\eta$ nie odwołuje się do uzusu semickiego. Prof. F. Delitzsch, dokonując retrowersji Nowego Testamentu na język hebrajski, preferuje interpretację, której dał wyraz w postaci:

\section{(...) בריכה על יד שער הצאן שנקראה (...)}

mi, kiedy recytować będziemy dzieło Jeremiasa z innych autorów, którzy korzystają właśnie z pierwodruku, zob. pierwowydanie: Die Wiederentdeckung von Bethesda, Joh 5, 2, Göttingen 1949, s. 6: „Es ist aber in Jerusalem beim Schafteich die auf aramäisch Bethesda genannte (Stätte) mit fünf Säulenhallen".

${ }^{8}$ Jedną z obiekcji J. Jeremiasa: „Der Teich kann nicht gut Bethesda heißen: ein Teich ist kein Haus” - kwituje D.J. Wieand (art. cyt. s. 393) w ten sposób: „However, „Beth” often has a wider connotation than house, as for example in Bethel or Bethlehem”. Należy zauważyć, że w angielskiej wersji wycofał się J. Jeremias z tego argumentu.

${ }^{9}$ Por. The Gospel according to John, t. 1, London 1966, s. 206.

${ }^{10}$ Por. שער הצאן.

11 Por. Jeremias, The Rediscovery, s. 9, n. 2: „However, $\pi \dot{u} \lambda \eta$, ,gate”, is only rarely omitted in gate names of this kind".

12 Żaden pisarz chrześcijański do XIII wieku nie dołączył do słowa probatike podmiotu pyle (brama) w nawiązaniu do J 5, 2, por. Jeremias, The Rediscovery of Bethesda, s. 10, nota 5. Zaś starożytna tradycja jednomyślnie opowiada się za sadzawką owczą, zob. jw., s. 10, nota 6.

${ }^{13}$ Por. H. van den Bussche, Guérison d'un paralytique à Jérusalem le jour du Sabbat, Jean 5 , 1-18, „Bible et vie chrétienne” 61 (1965) 18-28, spec. s. 19.

${ }^{14}$ Por. John V,2 and the Pool of Bethesda, art. cyt., s. 393. 
Rodzajnik określony $\mathfrak{\eta}$ może oddawać w języku hebrajskim zarówno zaimek względny $ש$ (który, która, które) jak i rodzajnik określony ה. Jeśli rodzajnik określony jest postawiony przed czasownikiem w czasie teraźniejszym, występuje wtedy właśnie w funkcji zaimka względnego. Okoliczność tę przedstawilibyśmy w zapisie jako: ha/niqrah (הנקראה). Czy zatem u podłoża błędnego odczytania greckiego rodzajnika $\eta$ nie stoi w tym wypadku nie wyciąganie właściwych wniosków z prawidłowości języka semickiego?

Można się pokusić o zaproponowanie jeszcze innego rozwiązania, na które naprowadził mnie w drugiej dekadzie lat siedemdziesiątych G. Gerleman.

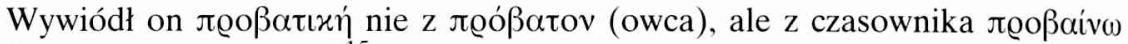
(wysuwać się naprzód) $^{15}$. Na bazie tej obserwacji, którą pomysłodawca nie

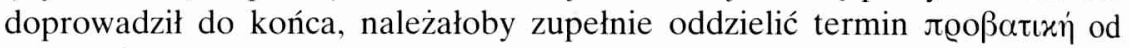
$\varkappa 0 \lambda v \mu \beta \eta \dot{\eta} \theta \alpha$. W tym wypadku przekład brzmiałby: „Na przedmieściach Jerozolimy znajduje się sadzawka zwana po hebrajsku Bethesda, zaopatrzona w pięć krużganków". Czy przypadkiem potwierdzenia tej propozycji nie znajdziemy u Pseudo Atanazego w jego Homilii o siewcy, gdzie czytamy: '́v

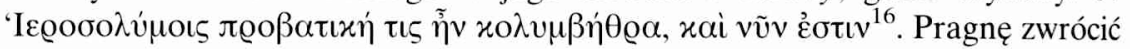
na tę propozycję baczniejszą uwagę, gdyż dostatecznie rozwiązuje ona prob-

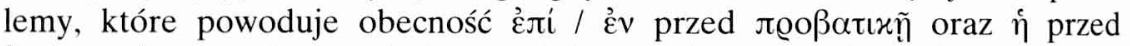

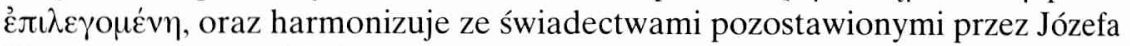
Flawiusza, o czym dalej.

2. Nazwa sadzawki. Sadzawka nazywała się ,po hebrajsku” ('Eß@aïotí) jak? Najpierw słowo hebraisti. Jan używa go w: 19, 13. 17. 20; 20, 16. Poza tym w Nowym Testamencie występuje jeszcze w Ap 9, 11; 16, 16. Według C.K. Barrett'a chodzi tu o nazwę w języku aramejskim ${ }^{17}$. Różnorodność wariantów nazwy „sadzawka” przedstawia się następująco:

1. B $\eta \theta \sigma \alpha \iota \delta \alpha-\mathrm{P}^{75} \mathrm{~B} \mathrm{~W}^{\text {supp }} 0125$ it $^{\text {aur,c }}$ vg syr $^{\mathrm{h}} \operatorname{cop}^{\text {sa,bo,ach/2 }}$ eth Diatessaron ${ }^{s}$ Tertulian, Hieronim; B $\eta \delta \sigma \alpha \iota \delta \alpha-\mathrm{P}^{66 / c} ; \mathrm{B} \eta \delta \sigma \alpha \iota \delta \alpha v-\mathrm{P}^{66 / *} ; \mathrm{B} \eta \sigma \sigma \alpha \iota \delta \alpha-\Psi$;

2. $\mathrm{B} \eta \theta \zeta \alpha \theta \alpha-\propto$ 33; Betzata - it'; $\mathrm{B} \eta \zeta \alpha \theta \alpha-\mathrm{L}$ it ${ }^{\mathrm{e}}$ Euzebiusz; Betzetha it $^{(\mathrm{b}), \mathrm{ff} / 2} ; \mathrm{B} \eta \lambda \xi \varepsilon \theta \alpha^{18}-\mathrm{D}$ it $\mathrm{i}^{(\mathrm{a}), \mathrm{d}, \mathrm{r} / 1}$;

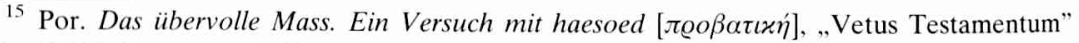
28 (1978) 151-164, spec. s. 163 n.

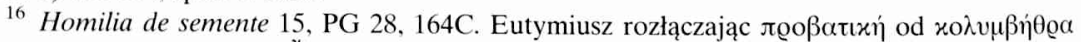

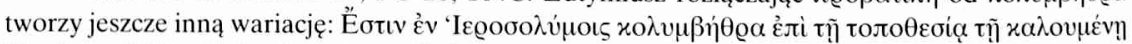

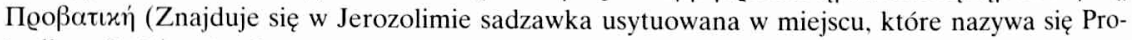
batike - B.G.), zob. Commentarius in Joannem, 5, 2, PG 129, 1208 A.

17 Por. The Gospel according to St. John, dz. cyt., s. 211.

$18 \mathrm{~J}$. Jeremias powiada, że „Belzetha, finally, a reading restricted to West, is nothing but a disfiguration of Bethzatha which probably originated by false analogy to Beelzebul" (The Rediscovery of Bethesda, s. 12.). 
3. B $\eta \theta \varepsilon \sigma \delta \alpha-\mathrm{A} \mathrm{C} \mathrm{K} \mathrm{X}{ }^{\mathrm{comm}} \Delta \Theta \Pi 078 f^{1} f^{13} 28565700892100910711079$ $119512161230124112421253^{\text {vid }} 134413651546164621482174$ Byz Lect it $^{(\mathrm{f}), \mathrm{q}}$ syr $^{\text {h/mg.gr }}$ arm geo Diatessaron, Dydym, Chryzostom, Cyryl Aleksandryjski; (Byt hsd - syr c,p,pal $^{19}$.

Już z pobieżnej obserwacji narzuca się nam nieuchronny wniosek: każdy z wariantów ma solidną tradycję tekstualną za sobą i nie latwo wyeliminować choćby jeden $\mathrm{z}$ nich $\mathrm{z}$ grona pretendentów do lekcji oryginalnej. Odchylenia konkretnych nazw w ramach poszczególnych odmian mogły być spowodowane przejściem $\delta \sigma w \sigma \delta, \theta w \zeta$ i odwrotnie oraz częstą ekwiwalencją $\alpha \iota$ i $\varepsilon^{20}$. Oprócz prób ustalenia genezy leksykalnej poszczególnych lekcji, egzegeci w sposób niezmordowany usiłują dotrzeć do semickiego podłoża określającego sadzawkę, by odszyfrować znaczenie jej greckiej nazwy.

Ad. 1) B B $\theta \sigma \alpha ı \delta \alpha$ (Bethsaida). Podłoże hebrajskie to: בית צידה (Beth sidah: dom rybaka). Lekcja ta jest najlepiej poświadczona tekstualnie (najstarsze papirusy) i najsłabiej opracowana naukowo. W Nowym Testamencie

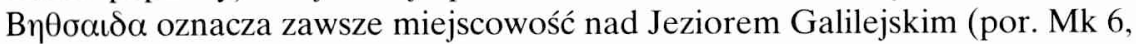
45). W jaki sposób zaaplikowano ją do sadzawki w Jerozolimie? Przez błąd kopisty? Wskutek znajomości Bethsaidy, a niewiedzy o Bethesdzie? J. Jeremias stwierdza, że papirusy powstałe w Egipcie nie zasługują na zaufanie, jeśli chodzi o ich znajomość nomenklatury geograficznej Palestyny ${ }^{21}$. D.J. Wieand, podtrzymując hipotezę oryginalności dla lekcji Bethesda, w szokujący sposób wyjaśnia pojawienie się Bethsaidy w tekście. To autor 21. rozdziału Ewangelii miał zamienić Bethesdę w Bethsaidę w interesie reinterpretacji wiary. Ryba bowiem, do której odwołuje nas samorzutnie Bethsaida, miała być kryptonimem Mesjasza, Eucharystii, chrztu i życia wiecznego 22 .

Ad. 2) $\mathrm{B} \eta(\theta) \xi \alpha \theta \alpha$ [Be(th)zatha]. Nie znaleziono dotąd jednoznacznego podłoża semickiego dla tego wariantu. Jedni upatrują go w: beth szitha (בית שיתא: dom owiec) ${ }^{23}$. Inni widzą tu wpływ świadectwa pozostawionego przez Józefa Flawiusza w Wojnie Żydowskiej. Okolicę, w której lokalizuje się sadzawkę, nazwał on terminem $B \eta \zeta \varepsilon \theta \alpha$ (Bezetha) - z greckim tłumaczeniem:

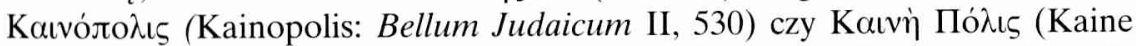
Polis: Bellum Judaicum V, 151 - Nowe miasto). Odpowiednikiem semickim dla

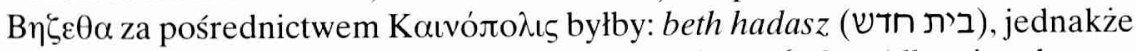

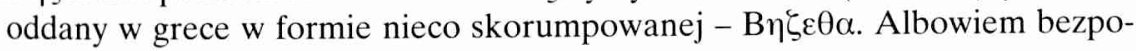

\footnotetext{
19 Por. Jeremias, The Rediscovery of Bethesda, dz. cyt., s. 11, nota 12.

20 Por. C.K. Barrett, The Gospel according to St. John, dz. cyt, s. 210.

21 Por. The Rediscovery of Bethesda, dz. cyt., s. 12.

22 Por. John V,2 and the Pool of Bethesda, art. cyt., s. 400-404.

23 Por. J. N. Sanders, A Commentary on the Gospel according to St. John, London 1968 ,
} s. 159. 


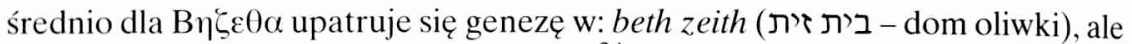
ta propozycja jest najmniej akceptowana ${ }^{24}$.

A. Wikenhauser ustala podłoże dla $\mathrm{B} \eta \zeta \alpha \theta \alpha$ (Bezatha), które jego zdaniem jest identyczne z $\mathrm{B} \eta \theta \zeta \alpha \theta \alpha$ (Bethzatha) i Bezetha, w aramejskim rdzeniu (בזעתא), przekładając go za pomocą: Spalte, Abschnitt, lecz ta identyfikacja pozostaje prawie odosobniona ${ }^{25}$. Zdaniem J. T. Milika odmianę Flawiuszową B $\lceil\xi \varepsilon \theta \alpha / \mathrm{B} \eta \zeta \alpha \theta \alpha$ da się wyprowadzić z nazwy Be-ždata, która pochodzi od tego samego rdzenia, co Beth eschdathain - nazwa sadzawki odkryta w zwojach z Qumran, o czym poniżej ${ }^{26}$.

Pomijając kwestię semickiego podłoża dla $\mathrm{B} \eta(\theta) \zeta \alpha \theta \alpha$ i jemu pochodnych

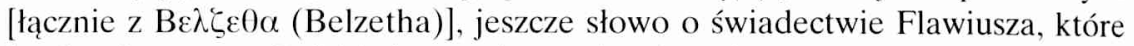
jest bardzo cenne. Dzięki niemu wiemy więcej, a mianowicie o tym, że teren, na którym znajdowała się sadzawka tworzył dzielnicę na przedmieściach miasta w sąsiedztwie bramy owczej.

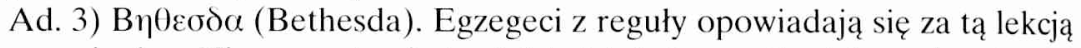
jako oryginalną. Nie ma natomiast wśród nich jednomyślności w zakresie etymologii tego słowa. Do czasu odkryć zwojów qumrańskich genezę semicką dla B $\eta \theta \varepsilon \sigma \delta \alpha$ upatrywano w: Beth hasda (בית חסדא: dom taski), co spontanicznie przywołuje na myśl jakość leczniczą wód sadzawki. Na radykalną reinterpretację nazwy B $\eta \theta \varepsilon \sigma \delta \alpha$ wpłynęło pewne odkrycie dokonane w Qumran. W trzeciej bowiem grocie qumrańskiej znaleziono zwój miedziany, a w nim wykaz 64. różnych miejsc w Judei, w których ukryto skarby. Na pozycji 57. listy precjozów (3Q15 XI, 12-14) widnieje wzmianka o skarbie schowanym w: Beth eschdathain (בית אשדתין), ,w sadzawce przy wejściu do mniejszego basenu”"27. Beth eschdathain zrównał z Bethesdą J.T. Milik ${ }^{28}$. Eschdathain jest liczbą mnogą (dualis) od rdzenia: nalewać, wlewać, wylewać, przelewać (אשד). Forma dualna wskazuje zawsze na dwie rzeczy tego samego rodzaju ${ }^{29}$. W tym wypadku mielibyśmy

${ }^{24}$ C.K. Barrett powiada, że „Bezetha may possibly be a corrupt form of בית חדש (beth hadash), „New House” (cf. the עיר חדשה, ir ha dashah, ,New City”), mentioned in Erubin 5, 6" (The Gospel according to St. John, dz. cyt., s. 210).

25 Por. Das Evangelium nach Johannes übersetzt und kurz erklärt, Regensburg ${ }^{3}$ 1961, s. 139. To samo, prawdopodobnie za nim, powtarza G. Schiwy, Weg ins Neue Testament. Johannes. Apostelgeschichte, Würzburg 1966, s. 58. Etymologię od szczeliny, pęknięcia wyprowadza H. van den Bussche, Guérison d'un paralytique à Jérusalem le jour du Sabbat, Jean 5,1-18, art. cyt., s. 19. Propozycję tę powtarza potem w: Jean. Commentaire de l'évangile spirituel, Bruges ${ }^{2} 1976$, s. 219 : Bézatha (Bezetha, Bethzetha) est le nom (étymologie: crevasse) du quartier au nord de la ville, séparé de la ville elle-même par une vallée dans laquelle se trouvait la piscine".

${ }^{26}$ Por. Le rouleau de cuivre de Qumran (3 Q15). Traduction et commentaire topographique, „Revue Biblique” 66 (1959) 321-357, spec. s. 347.

27 Tamże s. 328: Tout près de là, à Bet Ešdatain, dans la piscine (là) où l'on entre dans son bassin (plus) petit: vase d'aromates l'h (et vase de) parfum de syr'”.

28 Do tej identyfikacji przychylił się J. Jeremias, zob. The Copper Scroll from Qumran, „,The Expository Times" 71(1960) 227-228. 
do czynienia, już na płaszczyźnie języka, z potwierdzeniem istnienia dwóch basenów sadzawki. Ostatecznie Bethesda w J 5,2 oznaczałaby nie: dom łaski, ale: dom wód (czyli dwóch basenów) ${ }^{30}$. M. Görg zaś w 1989 r. powraca do wersji Beth hasda (בית חסדא). Wspierając się toponimem qumrańskim, ustala dla Beth hasda inną wykładnię etymologiczną i znaczeniową. Korzeniem dla hasda (חסא) ma być według niego czasownik pogłębiać (סד - vertiefen). W oparciu o ten rdzeń stwierdza on, że Beth hasda oznacza nieckę, wgłębienie. Zaś w odniesieniu do świadectwa z 3 groty qumrańskiej mielibyśmy tu wzmiankę o dwóch nieckach, które na gruncie terminologii, a więc na pierwszym planie, uwypuklają topografię rozważanego miejsca ${ }^{31}$.

3. Konstrukcja sadzawki. W oparciu o J 5,2 i pisma pewnych Ojców Kościoła długo wyobrażano sobie sadzawkę w kształcie pięciokąta otoczoną portykami, choć istniały przecież inne, bardziej precyzyjne świadectwa. Wśród nich na pierwszym miejscu należy wymienić Euzebiusza z Cezarei, który wie o istnieniu dwóch basenów ${ }^{32}$. Cyryl zaś Jerozolimski w homilii o uleczeniu

${ }^{29}$ Oto komentarz topograficzny J.T. Milika do 3 Q15 XI,12: בית אשדתין, de XI, 12 est essentiellement un grand réservoir rectangulaire, et évidemment double si l'on en juge par la finale du mot principal. Malgré la fluctuation curieuse de la désinence, on reconnaîtra aisément le même nom de lieu en:

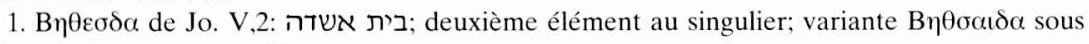
l'influence du toponyme galiléen;

2. בית אשדתין de 3 Q15; deuxième mot au duel; un toponyme du même quartier qui exprime aussi l'idée du double est X $\alpha \phi \varepsilon v \alpha \theta \alpha$ (kaphelata) de I Mac. XII,37;

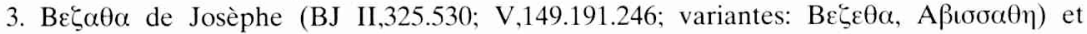

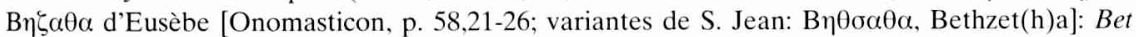

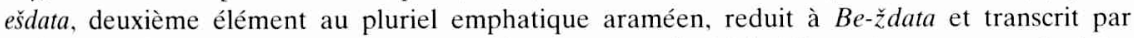
B $\eta \zeta \alpha \theta \alpha$, où $\zeta$ correspond à $\check{z} d$ comme en $\mathrm{A} \zeta \omega$ to venant de $A \check{z} d o d$. Rappelons que pour Josèphe c'est le nom du quartier entier, qui s'appelle donc d'après son monument le plus insigne et qui remplaa le toponyme qui vient d'être cité, exprimant également la dualité.

Quelle que soit la vraie étymologie du deuxième élément du mot, ,ן אשדתין (double versant?), les chrétiens araméophones de Jérusalem le rattachaient à la racine araméenne 'šd, verser (l'eau, le sang)", puisqu'ils remplissaient une piscine des eaux des averses et coloraient l'autre du sang que

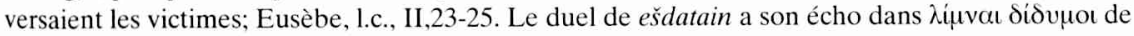
la $\gamma 0 \lambda v \mu \beta \eta \dot{\eta} \theta \alpha$ (אשיח de XI,12) chez Eusèbe et dans piscinae gemellares du Pèlerin de Bordeaux. Eusèbe emploie le me\$me terme „lac" que l'auteur du catalogue, mais celui-ci est plus précis puisqu'il semble faire une distinction entre le bassin plus grand, celui du sud, et מומית (diminutif de (י), XI, 13, ,bassin (plus) petit”, qui est celui du nord” (Le rouleau de cuivre de Qumran (3 Q15), s. 347-348).

${ }^{30}$ Por. R.E. Brown, The Gospel according to John, dz. cyt., s. 207.

${ }^{31}$ Por. Betesda: „Beckenhausen”, „Biblische Notizen” 49 (1989) 10.

32 Por. Onomasticon, ed. E. Klostermann, GCS 11/1, s. 58, 21-26: B $\eta \xi \alpha \theta \dot{\alpha}$ (Ioh 5, 2).

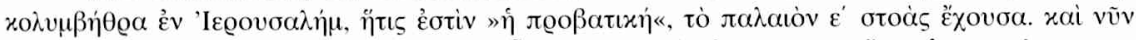

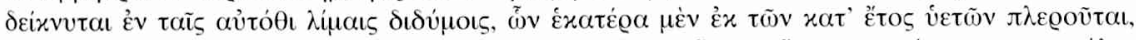

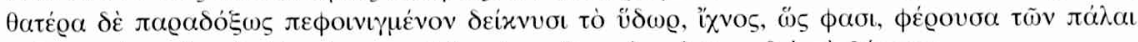

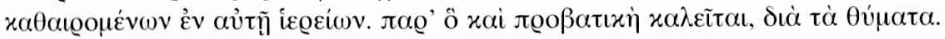


paralityka jeszcze bardziej precyzuje jej opis: „W Jerozolimie była sadzawka owcza, zaopatrzona w pięć portyków. Cztery okrążały ją, piąty był pośrodku. I w nim leżało mnóstwo cierpiących" (tłum. - B.G) ${ }^{33}$. Ustalenia tego miejscowego biskupa potwierdzi później Teodor z Mopswestii $(† 428)$, który dodaje: "quattuor enim circumdantes eam, unus erat in medio" (okrążały ją cztery [portyki], w środku był inny - B.G. ${ }^{34}$.

Te i jeszcze inne podobne im opisy potwierdziły właśnie odkrycia archeologiczne. Wykopaliska bowiem odsłoniły dwa baseny, północny i południowy, o kształtach trapezoidalnych nieregularnych. Przedzielała ich grobla o szerokości sześć i pół metra. Były one niezależne i jednostronnie skolerowane ze sobą. Zaopatrzone też one zostały w system kanałów odprowadzających wo$\mathrm{dę}^{35}$. Zbiorniki wodne miały powstać wskutek zamknięcia doliny Es-Sahireh i wykorzystania jej naturalnego ukształtowania, pooranego grotami ${ }^{36}$. A. Duprez twierdzi, że nie zasilało ich żadne źródło ${ }^{37}$, co wydaje się stać w sprzeczności w danymi Ewangelii, w której jest mowa o okresowym poruszaniu się wody; ich przeznaczeniem było zaopatrywać świątynię w wodę ${ }^{38}$. Istnienie tej sadzawki poświadcza prawdopodobnie już list Arysteasza z I wieku przed Chrystusem. Być może Syrach $(50,3)$ właśnie o niej wspomina, przypisując jej budowę Szymonowi synowi Oniasza $(220-195)^{39}$. Jednakże znalezione w czasie ekspedycji archeologicznej monety pochodzą dopiero z okresu od Hasmoneusza Aleksandra Jannaja do 68 roku $^{40}$.

W świetle danych archeologii problematycznie przedstawia się też sprawa z portykami. Nie znaleziono praktycznie żadnych kolumn, a resztki odkopanych pochodzą z bazyliki bizantyńskiej, wzniesionej parę wieków po Chrystusie w obrębie całego kompleksu. Czy w tej sytuacji „quinque porticus” nie należy traktować jako pięć krużganków niekoniecznie skonstruowanych w oparciu

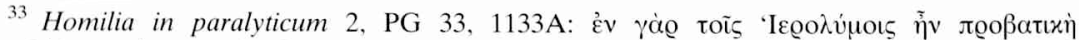

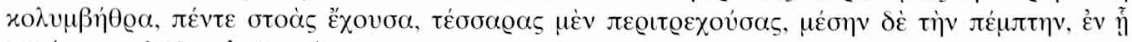

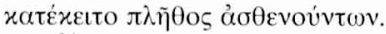

34 Tłumaczenie łacińskie podaję za: J. M. Vosté, Theodori Mopsuesteni Commentarius in Evangelium Johannis Apostoli, CSCO 116, 70. W katenie nr 61 do J 5, 2, błędnie przypisanej Orygenesowi przez E. Preuschen'a (GCS 10, s. 533, 2-3), w rzeczywistości znajdziemy taką oto

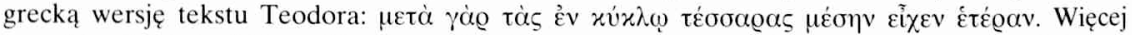
o problemie błędnej identyfikacji powyższej kateny zob. J. Jeremias, The Rediscovery of Bethesda, dz. cyt., s. 18 , nota 39.

35 Por. Jeremias, jw., s. 37

36 Por. A. Duprez, La Piscine Probatique, „Bible et Terre Sainte” 86 (1966) 4-15, spec. s. 8 .

37 Por. tamże, s. 5.

38 Por. A. Duprez, Probatique (Piscine), w: Dictionnaire de la Bible VIII 606-621, spec. s. 606-608.

39 Por. A. Duprez, La Piscine Probatique, art. cyt., s. 6.

${ }^{40}$ Por. A. Duprez, Probatique (Piscine), dz. cyt., s. 617. 
o kolumny? $?^{41}$ A. Duprez idąc za P. Benoit stawia hipotezę, że pięć portyków wskazuje na pięć grot (odkryto ich więcej) przy sadzawce z małymi kamiennymi basenami, w których, jak się zdaje, stosowano hydroterapię ${ }^{42}$, na co zdają się też wskazywać różne wotywne przedmioty.

4. Sadzawka: jest, czy była w momencie redakcji Ewangelii? Szkielet wy-

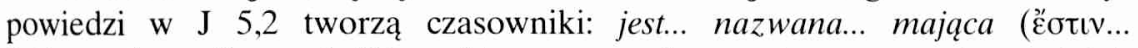

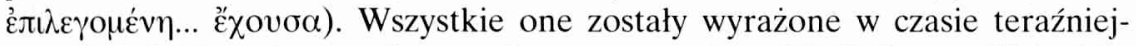
szym i zdają się wskazywać na to, że w momencie redakcji Ewangelii istniała jeszcze nietknięta sadzawka i portyki. Najbardziej intryguje badaczy pierwszy, przewodni termin हैotıv, i głównie na nim skupiają się hipotezy usiłujące wyjaśnić pozostałe formy temporalne. Sprawa nie jest jednak taka prosta, albowiem przekazy starożytne nie są jednoznaczne w tym względzie. Wspomniany Cyryl Jerozolimski mówi o sadzawce w konwencji czasu przeszłego, a więc odwrotnie do nieco wcześniejszego świadectwa pozostawionego przez pielgrzyma z Bordeaux: ,[...] venimus ad piscina natatoria, quae habet quinque porticus, ex quibus una habet basilicam sanctae Mariae"43.

D.B. Wallace w roku 1990 stworzył drobiazgowe compendium do tego zagadnienia w artykule pt. John 5, 2 and the Date of the Fourth Gospel ${ }^{44}$. Kwestię wyjaśnienia wymowy czasownika ,jest” rozłożył on na pięć następujących hipotez: 1) Autor lub redaktor dzieła (mieszkający poza Palestyną) pomylił się: nie wiedział, że sadzawka została zburzona podczas wojny Żydów z Rzymem w latach 66-70 n.e. 2) Użyto tu czasu teraźniejszego w sposób nietypowy, opisując za jego pomocą coś, co rzeczywiście już nie istnieje, a istniało. 3) Ëotı jest tutaj praesens historicum - zwyczajem opowiadania o przeszłości za pomocą czasu teraźniejszego. 4) Sadzawka na pewno, a portyki może, przetrwały katastrofę powstania. 5) Ostatni redaktor dzieła (tworzący ok. 100. roku) nie zamienił czasów teraźniejszych z jego pierwszej redakcji dokonanej przed zburzeniem obiektu ok. 70 roku. Choć autor najwięcej wagi przywiązuje do piątej hipotezy, pokazuje braki wszystkich, łącznie z preferowaną przez siebie ${ }^{45}$.

${ }^{41}$ Por. A. Duprez, La Piscine Probatique, art. cyt., s. 8; zob. także, Jésus et les dieux guérisseurs. À propos de Jean 5, Paris 1970, s. 37-42.

${ }^{42}$ Por. P. Benoit, Découvertes archéologiques autour de la piscine de Bethesda, w: Jerusalem through the Age: The Twenty-Fifth Archeological Convention, ed. J. Aviram, Jerusalem 1968, 48-57, spec. s. 56.

${ }_{43}$ Por. J. Jeremias, The Rediscovery of Bethesda, dz. cyt., s. 38.

44 „Biblica” 71(1990) 177-205.

45 Por. jw., s. 182-205. 


\section{THE POOL OF BETHESDA (Jo 5, 2) IN PATRISTIC AND CONTEMPORARY INTERPRETATION}

(Summary)

The second verse of the fifth chapter of the Gospel according to John is a true crux exegetarum indeed. Nobody may feel responsible for the interpretation of the meaning of this passage since any translation is merely an interpretation of the original represented by the preferance of the single translator. This ambiguity is a main obstacle to place and name the Sheep (?) Pool in Jerusalem. However the Pools structure is no more doubtful. Following the suggestion of G. Gerleman who derived the name probatike not from probaton (sheep) but from the verb probaino (to move forward) the next step is to separate the terms: probatike (suburb?) and kolymbethra (pool) and form the following translation of this passage: „On the suburbs of Jerusalem there is a pool named in Hebrew Bethesda (?) with five collonades". 